\title{
The Effectiveness of Azolla pinnata in Inhibiting the Growth of Salmonella typhi
}

\author{
Evy Ratnasari E. ${ }^{1 *}$, M. Sungging Pradana ${ }^{1}$ \\ ${ }^{1}$ Faculty of Health Sciences, Universitas Maarif Hasyim Latief, Sepanjang, Indonesia \\ *email:evysains@dosen.umaha.ac.id
}

\section{Article Info}

Key word:

Azolla pinnata

Salmonella typhi

Herbal

Article history:

Submitssion: 05-11-2018

Accepted: 13-02-2019

\begin{abstract}
Human digestive tract infections can be caused by viruses, bacteria and protozoa. Bacterial resistance to antibiotics can frustate therapy with antibiotics. Today many researchers develop herbal medicines from plants for microbial infections. The benefits of medicinal plants depend on several components of chemicals that can have an influence on the human body. One of the plants that can be used is Azolla. Azolla has many nutrients and phytochemical compunds such as flavonoid, tannin, and saponin which have antimicrobial activity. This study used dried Azolla extract which was divided into several doses, namely 20\%, 40\%, 60\%, 80\% and 100\% b/v. Azolla extract activity test was carried out by observing the presence of inhibition zones formed after incubation. Azolla extract test results obtained all doses in the resistance category with a diameter of no more than $10 \mathrm{~mm}$. One way Anova test obtained a significance value of $0.000<\alpha=0.05$, which means that there is a difference between the administration of Azolla pinnata extract dose to its ability to inhibit growth of Salmonella typhii. Duncan test showed that the treatment of Azolla pinnata 60\%, $80 \%$ and $100 \%$ of Salmonella typhii showed results that were not significantly different. The results of the study concluded that Azolla extract can be used to inhibit the growth of Salmonella typhii bacteria, so that it can be develop into traditional medicine.
\end{abstract}

Copyright @ 20XY Universitas Islam Negeri Raden Fatah Palembang. All Right Reserved

\section{Introduction}

Human digestive tract infections can be caused by viruses, bacteria and protozoa. Bacterial infections can be caused by several species including Shigella flexneri, Shigella disentriae, Escherichia coli, Vibrio cholera, Salmonella typhii (the cause of typhoid fever), Campylobacter jejuni, Staphylococcus aureus, Bacillus cereus, Clostridium perfringens (Zein, 2004).
Bacterial resistance to antibiotics can frustrate therapy with antibiotics. The causes of resistance are caused by improper use of antibiotics, such as inappropriate dosage use, irregular use, and also treatment in a short time (Mithraja,M.J., Johnson M.A., Mony M., Zachariah M.P., 2011). Many antibiotics are used to cure infections by pathogenic bacteria which ultimately are resistant to 
these bacteria. Therefore, many researchers develop herbal medicines from plants for microbial infections (Kumar, 2014; Tumane, Meshram, \& Wasnik, 2014).

Plants are one of the producers on earth that can produce their own food through photosynthesis. For humans, besides being used for food sources, plants can also be used as medicinal raw materials. Medicinal plants have become traditional medicines as well as modern medicines that can be used for primary health care. World Health Organization (WHO) has recommended traditional medicine as a safe drug for microbial and non-microbial diseases (Mithraja,M.J., Johnson M.A., Mony M., Zachariah M.P., 2011).

The benefits of medicinal plants depend on several chemicals that can have an influence on the human body. Important components in the composition of plant bioactive substances that can be used as antiinfective agents include alkaloids, tannins, flavonoids, phenolic compounds (Mithraja,M.J., Johnson M.A., Mony M., Zachariah M.P., 2011) tannins, steroids, terpenoids, saponins, and phytosterols (Gurnani, Gupta, Mehta, \& Mehta, 2016). The bioactive substance is a secondary metabolite produced by plants, one of which is Azolla.

Azolla is a water plant that lives floating on the surface of the water. The name Azolla comes from Greek, namely azo (dries) and Allyo (dead) which means the plant dies if it is dry (Rathaur, John, \& Ramteke, 2012). Azolla is included in the Azollaceae family and is a good source of protein that contains almost all types of amino acids, minerals such as iron, calcium, magnesium, potassium, phosphorus, manganese and others in addition to a large number of precursors of vitamin A, beta-carotene and vitamin $\mathrm{B}_{12}$ (Dm, Prasad, Jagadeeswararao, Jayalaxmi, \& Kumar, 2014).

The abundance of nutrients contained in Azolla plants so that Azolla is widely used, among others, as biofertilizers in rice plants in rice fields, green manure, treatment of wastewater from livestock (Jangwattana \&
Iwai, 2010), salt soil reclamation, bioremediation, mosquito repellent, weed control, biogas production, bioenergy, human food, components in the diet in space, nutritional supplements for livestock (Rathaur et al., 2012) and phytoremediation agents (Al-baldawi, Rozaimah, \& Abdullah, 2012).

Azolla also contains phytochemical compounds such as flavonoids, tannins and saponins which have antimicrobial activity, anti fungi, anti-cancer, antioxidants, antiinflammatory to hypercholesterolemia and hyperglycemia (Mithraja,M.J., Johnson M.A., Mony M., Zachariah M.P., 2011). The content of this compound in Azolla has not been widely studied for its effects on human diseases, especially those caused by bacterial infections. So it is necessary to do research on the benefits of the content of phytochemical compounds found in Azolla.

\section{Materials and Methods \\ Sample Preparation}

The harvested Azolla is then dried in an oven with a temperature of $70{ }^{\circ} \mathrm{C}$. the dried material is then weighed and mashed using a blender until it becomes powder (Jangwattana \& Iwai, 2010).

\section{Identification of Chemical Compounds}

Phytochemical compounds include alkaloids, tannins, saponins, flavonoids, and anthraquinones.

\section{Azolla pinnata Extract Preparation}

Azolla which has been mashed into powder is weighed as much as $10 \mathrm{~g}$ and put in a glass jar and soaked (macerated) with $100 \mathrm{ml}$ of methanol, then cover the jar with aluminum foil and incubate for 2 days at room temperature with occasional stirring time. The results of maceration were filtered using Whatman No. filter paper. 1 and then evaporation using rotary evaporatory at $80^{\circ}$ C. the results of the evaporation in the form of a thick pure extract were weighed and stored in a jar before being used for testng (Noor Nawaz A et al., 2014). 


\section{Test Solution Preparation}

Test solution is made at a dose of $20 \%$; $40 \% ; 60 \% ; 80 \%$ and $100 \%$ b / v by weighing $0.2 \mathrm{~g} ; 0.4 \mathrm{~g} ; 0.6 \mathrm{~g} ; 0.8 \mathrm{~g}$; and $1 \mathrm{~g}$ of Azolla extract was then dissolved in $1 \mathrm{ml}$ of sterile aquades (Deby, A., Fatimawali, Dan Wiyono, 2012).

\section{Control Preparation}

Positive control was made from the Ciprofloxacin $500 \mathrm{mg}$ tablet, by means of 1 Ciprofloxacin tablet crushed and then weighed and equalized with $500 \mathrm{mg}$ and dissolved in $100 \mathrm{ml}$ sterile distilled water. Negative control using sterile distilled water (Deby, A., Fatimawali, Dan Wiyono, 2012).

\section{Bacterial Isolate Preparation}

Isolate of Salmonella typhii bacteria stored in the NAS at $4^{\circ} \mathrm{C}$, used as a stock of bacteria in subsequent tests (Tumane et al., 2014).

\section{Test Bacterial Suspension}

Test isolates that have been rejuvenated, taken with ose and then suspended into a tube containing 5-10 $\mathrm{ml}$ of sterile PZ until the same turbidity is obtained as standard Mc Farland 0.5 (Forbes B.A, Daniel F. Sahm, 2002).

\section{Antibacterial Activity Test of Azolla pinnata Extract}

$10 \mathrm{ml}$ of MHA was poured into sterile petri dishes and allowed to solidify (as a base layer). After the base layer is compacted, 3-5 steel winners are placed a and the distance between the wallets is arranged.

The bacterial suspension is mixed into $25 \mathrm{ml}$ NA media then the mixture is poured into a petri dish which has been given steel as a second layer (seed layer), and allowed to solidify. The steel barrier is lifted aseptically from the petri dish, so that the well is formed. Azolla pinnata extract solution with various doses, negative controls and positive controls each placed in a different well as much as 50-100 $\mu$, incubated at $37^{\circ} \mathrm{C}$ for 24 hours. Observation of the inhibition zone formed after incubation and its diameter measured using calipers (Forbes, B., Sahm, D., and Weissfeld, 2007).

\section{Data Analysis}

The data obtained were analyzed using one-way ANOVA test to determine the effect of Azolla pinnata extract treatment at various doses. If the effect is obtained, it is continued with the Duncan test to find out the most effective dose.

\section{Results and Discussion}

After the inhibitory test of Azolla pinnata extract against Salmonella typhi bacteria was obtained as shown in table 1 .

Table 1. Potential Test Results of Azolla pinnata Extract against Salmonella typhi bacteria

\begin{tabular}{ccc}
\hline $\begin{array}{c}\text { Variance of } \\
\text { Dose }\end{array}$ & $\begin{array}{c}\text { Average } \\
\text { Inhibited Zone } \\
\text { Diameter } \\
\text { (mm) }\end{array}$ & Category \\
\hline $\mathrm{DA}_{0}$ & 0 & $\mathrm{R}$ \\
$\mathrm{DA}_{1}$ & 44,57 & $\mathrm{~S}$ \\
$\mathrm{DA}_{2}$ & 0 & $\mathrm{R}$ \\
$\mathrm{DA}_{3}$ & 7,99 & $\mathrm{R}$ \\
$\mathrm{DA}_{4}$ & 8,76 & $\mathrm{R}$ \\
$\mathrm{DA}_{5}$ & 8,86 & $\mathrm{R}$ \\
$\mathrm{DA}_{6}$ & 9,42 & $\mathrm{R}$ \\
\hline
\end{tabular}

Note: $\mathrm{DA}_{0}=$ negative control; $\mathrm{DA}_{1}=$ positive control; $\mathrm{DA}_{2}=$ Dose $20 \% ; \mathrm{DA}_{3}=$ Dose $40 \% ; \mathrm{DA}_{4}=$ Dose $60 \% ; \mathrm{DA}_{5}=$ Dose $80 \% ; \mathrm{DA}_{6}=$ Dose $100 \%$. R (Resisten $)=\leq 10 \mathrm{~mm} ; \mathrm{I}$ $($ Intermediet $)=11-16 \mathrm{~mm} ; \mathrm{S} \quad($ Susceptible $)=\geq 17 \mathrm{~mm}$ (NCCLS,2005; Soleha, 2015)

The data obtained are then tested statistically using one way ANOVA by first testing the normality and homogeneity. The results of the normality test (KolmogorovSmirnov) obtained a significance value of $0.793>\alpha=0.05$, meaning that the data were normally distributed. The homogeneity test results (Levene test) obtained a significance value of $0,000<\alpha=0.05$, meaning that the data were not homogeneously distributed so data transformation was needed and a significance value of $0.055>\alpha=0.05$ was obtained which meant that the data were homogeneous. One way Anova test obtained a significance value of $0.000<\quad \alpha=$ 0.05 , which means there is a difference 
between the Azolla pinnata extract dose for its ability to inhibit the growth of Salmonella typhi. The test was followed by Duncan's test to find out whether there were significant differences or not between doses. Duncan test results can be seen in table 2 .

Table 2. Mean Values \pm SD of Azolla pinnata Extract Potential at Various Dosage Variations in Inhibiting Salmonella typhi growth

\begin{tabular}{ccc}
\hline Number & Dose & $\begin{array}{c}\text { Average Inhibited Zone } \\
\text { Diameter (mm) }\end{array}$ \\
\hline 1 & $\mathrm{DA}_{0}$ & $0^{\mathrm{a}}$ \\
2 & $\mathrm{DA}_{1}$ & $44,57^{\mathrm{d}}$ \\
3 & $\mathrm{DA}_{2}$ & $0^{\mathrm{a}}$ \\
4 & $\mathrm{DA}_{3}$ & $7,99^{\mathrm{b}}$ \\
5 & $\mathrm{DA}_{4}$ & $8,76^{\mathrm{b}, \mathrm{c}}$ \\
6 & $\mathrm{DA}_{5}$ & $8,86^{\mathrm{b}, \mathrm{c}}$ \\
7 & $\mathrm{DA}_{6}$ & $9,42^{\mathrm{c}}$ \\
\hline
\end{tabular}

Note: The average value of the inhibitory zone diameter followed by different letters shows significant differences based on the Duncan test at the level of $5 \%$

Salmonella $s p$ is one of the pathogenic bacteria that causes gastrointestinal tract infections. Salmonella sp bacteria if ingested and enter the body will attack the gastrointestinal tract which includes the stomach, small intestine or column so as to cause enteritis infection, typhoid fever, diarrhea and vomiting (Brooks, GF, 2004). It needs to be treated if attacked by Salmonella bacteria.

One treatment that can be used is herbal medicine. One of the herbs that can be used is Azolla extract. In this study, Azolla extract was tested for its effectiveness in inhibiting the growth of typhii Salmonella. The results showed that the dose of $100 \%$ Azolla extract had the widest inhibition diameter of the other doses even though it was still in the same category, which was resistant (R). This can be caused because Azolla extract contains phytomomic compounds such as flavonoids, tannins and saponins which have antimicrobial activity, anti fungi, anti-cancer, antioxidants, antiinflammatory to hypercholesterolemia and hyperglycemia (Mithraja,M.J., Johnson M.A., Mony M., Zachariah M.P., 2011). Azolla also contains antioxidants that can fight free radicals and phenolic compounds (Noor Nawaz A et al., 2014).

In this study, phytochemical compounds that can inhibit the growth of Salmonella typhii bacteria are possible in the form of phenols and flavonoids. Research conducted by Gurnani et al., (2016) also showed that the azolla pinnata plant extract had inhibitory activity in Staphylococcus aureus, Pseudomonas aeruginosa, and Escherichia coli bacteria.

Phytochemical compounds are nonnutrient chemical components or bioactive components of plants (Doughari, 2009) which serves to protect plants from the threat of fungi, bacteria, viruses, nematodes and others (Mithraja,M.J., Johnson M.A., Mony M., Zachariah M.P., 2011). The mechanism of phytochemical action has been explained. Plant extracts and essential oils can show various modes of action against bacterial strains, such as interference with the cell membrane's phospholipid double layer (Rao \& Gan, 2014).

Statistical tests using one way Anova and Duncan test showed that the treatment dose of Azolla pinnata extract $60 \%, 80 \%$ and $100 \%$ of Salmonella typhii showed results that were not significantly different, so it can be said that the dose of $60 \% 80 \%$ and $100 \%$ can inhibit Salmonella thypi growth.

\section{Conclusion}

The results showed that Azolla extract can be used to inhibit the growth of Salmonella thyphi bacteria, so that it can be developed into traditional medicine.

\section{References}

Al-baldawi, I. A., Rozaimah, S., \& Abdullah, S. (2012). Preliminary Test of Hydrocarbon Exposure on Azolla pinnata in Phytoremediation Process, 33, 244-247.

Brooks, GF, B. J. and M. S. (2004). 2004 (twenty sec). Medical Publishing Division. https://doi.org/10.1002/146518

Deby, A., Fatimawali, Dan Wiyono, W. I. (2012). Uji Aktifitas Antibakteri Ekstrak 
Etanol Daun Mayana. Jurnal Pharmacon. Retrieved from https://ejournal.unsrat.ac.id/index.php/ph armacon/article

Dm, C., Prasad, R. M. V, Jagadeeswararao, S., Jayalaxmi, P., \& Kumar, D. S. (2014). A study on the nutritive value of Azolla pinnata, 2(1), 13-15.

Doughari, J. H. (2009). Phytochemicals : Extraction Methods, Basic Structures and Mode of Action as Potential Chemotherapeutic Agents.

Forbes, B., Sahm, D., and Weissfeld, A. (2007). Bailey \& Scott's Diagnostic Microbiology. New York: ELSEVIER, Mosby.

Forbes B.A, Daniel F. Sahm, A. S. W. (2002). Diagnostic Microbiology (eleventh E). New York: Andrew Allen.

Gurnani, N., Gupta, M., Mehta, D., \& Mehta, B. K. (2016). Chemical composition, total phenolic and flavonoid contents, and in vitro antimicrobial and antioxidant activities of crude extracts from red chilli seeds (Capsicum frutescens L.). Journal of Taibah University for Science, 10(4), 462-470.

https://doi.org/10.1016/j.jtusci.2015.06.0 11

Jangwattana, R., \& Iwai, C. B. (2010). Phytochemical studies on Azolla pinnata R. International Journal of Environmental and Rural Development, 1(2), 23-27. Retrieved from http://iserd.net/ijerd12/12023.pdf

Kumar, A. (2014). Antimicrobial Activity and Phytochemical Analysis of Citrus Fruit Peels -Utilization of Fruit Waste, (October).

Mithraja,M.J., Johnson M.A., Mony M., Zachariah M.P., and S. J. (2011). Phytovhemical Studies on Azolla pinnata R. Br., Marsilea minuta L. and Salvinia molesta Mitch. Journal of Tropical Biomedicine, S26-S29.

Noor Nawaz A, Junaid, S., Dileep, N., Rakesh, K. N., R, P. K. T., \& Microbiology, A. (2014). Antioxidant Activity of Azolla Pinnata and Azolla
Rubra - A Comparative Study, 2(10), 719-723.

Rao, P. V., \& Gan, S. H. (2014). Cinnamon : A Multifaceted Medicinal Plant, 2014. https://doi.org/10.1155/2014/642942

Rathaur, P., John, S., \& Ramteke, P. W. (2012). Azolla: An aquatic pteridophyte with great potential, (January).

Tumane, P. M., Meshram, V. G., \& Wasnik, D. D. (2014). Comparative study of antibacterial activity of peel extracts of Citrus aurantium L. (Bitter Orange) and Citrus medica L. (Lemon) against clinical isolates from wound infection. International Journal of Pharma and Bio Sciences, 5(1), 382-387.

Zein, U. (2004). acute diarrhea caused by bacteria, 1-15. 